\title{
逆音響解析を用いた音源同定の精度向上に関する研究*
}

中野 陽介*1, 吉村 卓也 ${ }^{* 2}$

\section{Precision Improvement of Identification of the Sound Source by Inverse Acoustic Analysis}

\author{
Yosuke NAKANO*1 and Takuya YOSHIMURA \\ *1 Tokyo Metropolitan Univ. Dept. of Mechanical Engineering \\ Minami-osawa 1-1, Hachioji-shi, Tokyo, 192-0397 Japan
}

This paper proposes a method improving precision of sound source identification by inverse acoustic analysis. The inverse acoustic analysis identifies a vibrational state for mechanical structures by measuring the radiated sound in many points and solving the inverse problem. In this analysis, the uniqueness of solution is not always guaranteed, and the problem is to avoid the instability of the inverse matrix in sound source identification. A numerical simulation is performed about a plate model, on which many point sources are assumed that radiate sound pressure by their vibration. Sound pressures are measured by many microphones and the inverse matrix is calculated from acoustic transfer functions. This paper presents two kinds of methods for changing the coordinates of measurement points in order to decrease the instability of the inverse matrix. One is the singular value sensitivity analysis and the other is the statistic approach by using normal distribution. Both methods are applied for the noise source identification of the plate, and the results are compared, and their features are discussed.

Key Words : Sound and Acoustics, Frequency Response Function, Modal Analysis, Inverse Problem

\section{1. 緒言}

機械構造物の騒音低減は, 工学的に極めて重要な課題の一つである(1). 自動車を例に上げると，ガソリンエン ジンを用いた従来の自動車に対して，環境重視や快適性向上の観点から騒音低減が求められている．また，一般 に普及し始めている電気自動車においても静肃化が問題となっており，よりいっそうの騒音低減が求められてい る．機械の低騒音化のためにはまず，騒音の原因となる音源を同定する必要がある．機械の音源同定を行う際， 接触型，あるいは非接触型の振動測定器を用いて振動データを測定するが，これらの同定方法は有効である一方 で問題点もいくつか指摘できる．例えば，接触型測定器を用いる場合，小型，あるいは軽量な機械に振動測定器 を直接取り付ける事により，測定に影響を及ぼす可能性が少なからず考えられる．また，複雑な機械に対しては 振動測定器そのものを取り付ける事が難しく, 測定が困難な場合もある. これより，機械が発生する音を多点で 測定する事により機械の振動状態を推定する逆音響解析も有効な手段であるといえる．この逆音響解析では解の 唯一性が必ずしも保証されておらず，また音源同定を行う際の逆行列の不安定性低減が大きな課題であり，これ に関する多くの研究が報告されているが(2) (5)，問題解決に十分に有効な方法は提案されていない.

本研究では放射音の問題を扱っており，単純な平板モデルの音源同定について数值シミュレーションを行い, 音源同定の精度向上のために逆行列の不安定性を低減させる事を目的とする．具体的には，想定される騒音源に 対して, 音圧の測定点数や測定点の座標位置が音源同定の精度に及ぼす影響を調べ，限られた音圧の測定点数に おいて，高精度な音源同定が可能となる測定条件について考察する.

${ }^{*}$ 原稿受付 2012 年 10 月 19 日

*1 学生員, 首都大学東京大学院 理工学研究科 機械工学専攻 （干192-0397 東京都八王子市南大沢 1-1）

*2 正員, フェロー, 首都大学東京大学院 理工学研究科 機械工学専攻

E-mail: nakano-yousuke1@ed.tmu.ac.jp 


\section{2. 理 論}

\section{$2 \cdot 1$ 逆音響解析（Inverse Acoustic Analysis)}

音源における振動速度と音圧は次の関係がある ${ }^{(5)}$.

$$
\{p\}=[H]\{v\}
$$

式(1)において， $\{p\}$ は $m$ 行の音圧ベクトル， $\{v\}$ は $n$ 行の振動速度ベクトル， $[H]$ は $m$ 行 $n$ 列の音響伝達関数行列 である.ここで逆音響解析とは，音圧を測定する事により振動速度を同定する事である. 行列 $[H] に$ 対して特異值 分解を行うと次式が得られる.

$$
[H]=[U]\left[\Sigma \llbracket[V]^{H}\right.
$$

ここで， $[U],[V]$ はユニタリ行列である. [ $[\Sigma]$ は行列 $[H]$ に関する特異值で構成される対角行列である. $i$ 番目の特 異值を $\sigma_{i}$ と表し, $[\Sigma]$ の対角要素である特異值は， $\sigma_{1} \geqq \sigma_{2} \geqq \cdots \geqq \sigma_{i} \geqq \cdots \geqq \sigma_{n}$ と表す.

行列の大きさを示す $m$ は音圧の測定点数であり, $n$ は機械構造物上の騒音源となる要素の個数である. 一般に $m>n$ であるため, これら音圧点と振動速度点の数は一致しない. 寸なわち， $[H]$ は長方行列となるため，この $[H]$ に対して擬似逆行列を求める.

$$
[H]^{+}=[V][\Sigma]^{+}[U]^{H}
$$

ここで $[\Sigma]^{+}$は次のように得られる.

$$
[\Sigma]^{+}=\left[\begin{array}{ccccc}
1 / \sigma_{1} & 0 & \cdots & \cdots & 0 \\
0 & 1 / \sigma_{2} & & & \vdots \\
\vdots & & \ddots & 0 & \vdots \\
0 & \cdots & 0 & 1 / \sigma_{n} & \cdots
\end{array}\right]
$$

式(3)を式(1)の両辺に左から乗じる事で次式が得られる.

$$
\{v\}=[H]^{+}\{p\}=[V \llbracket \Sigma]^{+}[U]^{H}\{p\}
$$

行列が特異の場合は $\sigma_{\mathrm{n}} \doteqdot 0$ となり $1 / \sigma_{\mathrm{n}}$ が発散する.このとき行列がランク落ち(rank-deficient)となるため, 逆行列 の不安定性の要因となる.

\section{2 - 2 音響伝達関数 (Acoustic Transfer Function)}

\section{$2 \cdot 2 \cdot 1$ 振動板による音の放射}

バフル平板上の表面にある点音源により放射される音波の速度ポテンシャル $\phi$ は次のように与えられる ${ }^{(6)}$.

$$
\phi=\frac{Q}{2 \pi r} e^{j(\omega t-k r)}
$$

ここで, $\omega$ は角周波数, $k$ は波数, $r$ は音源と測定点の距離， $Q$ は体積速度である. 式(6)は剛壁の表面上にある点 音源によって壁面の前方の半空間に形成される音場を表現している. よって，剛壁面の一部分に，ある大きさの 振動板があり音を放射している場合には，振動板を微小面積要素に分割し，それぞれの面積要素が点音源として 音を放射していると考えられる．したがって，音の放射の観点から，振動板は分布点音源であると考える事が出 来る.

\section{$2 \cdot 2 \cdot 2$ 音響伝達関数の定義}

音圧 $P$ と排除体積速度 $V$ は次のようになる.

$$
\begin{aligned}
& P=\rho \frac{\partial \phi}{\partial t}=j \omega \rho \frac{Q}{2 \pi r} e^{j(\omega t-k r)} \\
& V=4 \pi r_{0}{ }^{2} v_{0} e^{j \omega t}=Q e^{j \omega t}
\end{aligned}
$$


これより，音速を $c$ ，平板要素の面積を $S$ とすると，音響伝達関数 $H$ は次のように得られる.

$$
H=\frac{P}{V} S=\frac{j S \omega \rho}{2 \pi r} \exp \left(-\frac{j \omega r}{c}\right)
$$

\section{3. 数值シミュレーションモデル}

\section{$3 \cdot 1$ 数值シミュレーションの概要}

数值シミュレーションモデルを図 1 に示す. 図 1 のように，音源を持つ構造物のモデルを 2 次元平板モデルと 仮定する. 平板モデルの大きさは $600 \mathrm{~mm} \times 600 \mathrm{~mm}$ であり, 平板モデルを 25 分割した要素の中心に点音源を配置 し，それぞれの点音源から放射された音を，アレイ状に配置した測定点によって測定する．図 1(a)，(b)の音圧測 定範囲はそれぞれ正方形，円形であり，平板から 300mm 離れた位置に配置される.

図 1(a)の測定点の $x, y$ 座標は，音源の $x, y$ 座標に等しく配置している. 図 1(b)の測定点は，座標原点の直上 に中央が来るように 1 点配置させ， $x$ 軸， $y$ 軸上に測定点が配置されるように，半径 $150 \mathrm{~mm}, 300 \mathrm{~mm}$ の同心円に それぞれ 8 点，16 点を等間隔に並べている.

音響伝達関数行列 $[H]$ は式(10)を用いて構成される．ここで，音速を $c=340 \mathrm{~m} / \mathrm{s}$ ，空気の密度を $\rho=1.2 \mathrm{~kg} / \mathrm{m}^{3}$ と して, 周波数を $100 \mathrm{~Hz}$ から $5000 \mathrm{~Hz}$ まで変化させる. 平板の一つの要素における面積は $S=0.0144 \mathrm{~m}^{2}$ である. 平 板モデルの要素数は 25 点であり, 測定点数を $m$ 点とすると, 音響伝達関数行列 $[H]$ は $m$ 行 25 列の行列となる.

$$
\left\{\begin{array}{c}
P_{1} \\
P_{2} \\
\vdots \\
P_{m}
\end{array}\right\}=\left[\begin{array}{cccc}
H_{1,1} & H_{1,2} & \cdots & H_{1,25} \\
H_{2,1} & H_{2,2} & \cdots & H_{2,25} \\
\vdots & \vdots & \ddots & \vdots \\
H_{m, 1} & H_{m, 2} & \cdots & H_{m, 25}
\end{array}\right]\left\{\begin{array}{c}
V_{1} \\
V_{2} \\
\vdots \\
V_{25}
\end{array}\right\}
$$

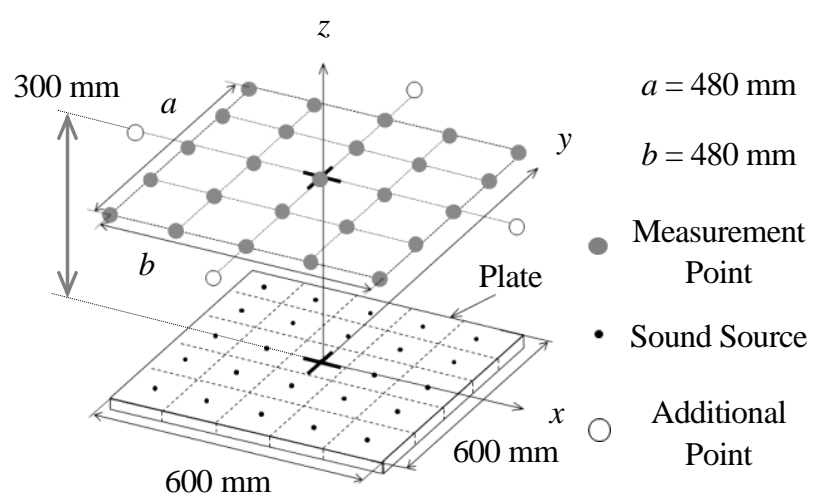

(a) Measurement area : square

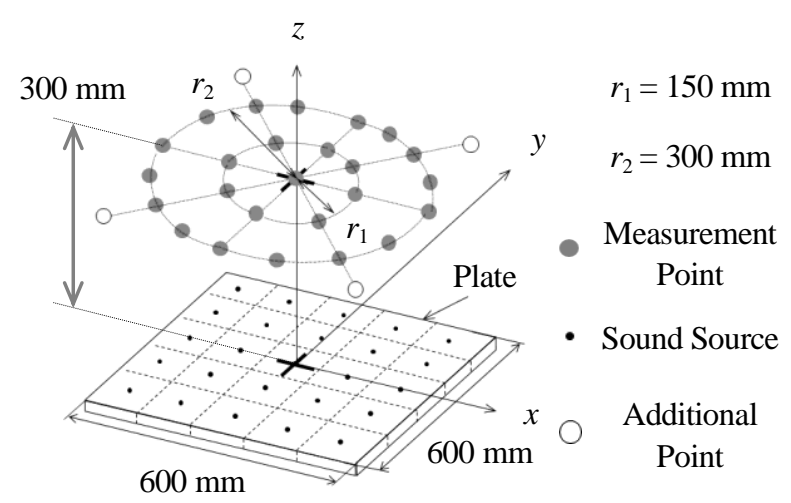

(b) Measurement area : circle

Fig. 1 Numerical simulation model

\section{$3 \cdot 2$ 数值シミュレーション結果}

数值シミュレーションの結果を図 2 に示寸. 図 2 の横軸は周波数, 縦軸は音響伝達関数の特異值を最大特異值 で正規化した值である. 図中の実線は，式(10)の音響伝達関数行列 $[H]$ を特異值分解して得られた $\sigma_{1}, \sigma_{2}, \cdots, \sigma_{25}$ の中で, 最小特異值を最大特異值で正規化した $\sigma_{25} / \sigma_{1}$ であり, 破線は最小特異值より一つ大きい特異值を最大特 異值で正規化した $\sigma_{24} / \sigma_{1}$ である. 点線は行列の特異性を判断する閾值(Threshold)を示しており, 本研究では測定 誤差等の影響を考慮して 0.01 とした. 図 2 から, $1400 \mathrm{~Hz}$ 以下の低周波数域での特異值は全般的に閾値を下回り, 
低い周波数ほど悪条件になる。これは音源の波長が長くなる事による本質的な問題と考えられ，この範囲を除く 領域を騒音解析領域とし，騒音源の同定を成立させる事を考える. 図 2(a)では音圧測定範囲を図 1(a)のように正 方形に配置し，図2(b)では図 1(b)のように円形に配置している. また，それぞれ測定点数を 25 点として計算して いる.

図2において $\sigma_{25} / \sigma_{1}$ と $\sigma_{24} / \sigma_{1}$ を比較する. 図 2(a)の縦に引いた実線は $3350 \mathrm{~Hz}$ となる周波数を示している. $\sigma_{25} / \sigma_{1}$ ではこの周波数付近における特異值が閾值を下回っており, 行列が特異に近くなるため, 音響伝達関数行列の逆 行列が不安定となる. 一方，この周波数における $\sigma_{24} / \sigma_{1}$ は閾值を下回らず，逆行列は安定となる．同様に，図 2(b) の縦に引いた実線は $3700 \mathrm{~Hz}$ となる周波数を示しており， $\sigma_{25} / \sigma_{1}$ ではこの付近での特異值が閾值を下回り， $\sigma_{24} / \sigma_{1}$ は闇值を下回らないため, 周波数 $3700 \mathrm{~Hz}$ において $\sigma_{25} / \sigma_{1}$ は不安定, $\sigma_{24} / \sigma_{1}$ は安定となる. よって, 最小特異值 を最大特異值で正規化した $\sigma_{25} / \sigma_{1}$ が閾值を上回るような測定点の配置ならば，音響伝達関数行列の逆行列の対角 成分である各特異值は改善され，この逆行列が安定となる事が分かる.

次に，音圧測定範囲を正方形及び円形に配置した結果の比較を行う. 図 2(a)では，3350Hz 付近の周波数にお いて特異值が闇值を下回り，2570Hz，4550Hz，4830Hz 付近の周波数における特異值が閾值に近い值となる。一 方，図 2(b)では，周波数が $3700 \mathrm{~Hz}$ 付近で特異值が閾值を下回るが，その他の音響解析領域内の周波数における 特異值は閾值を十分に上回る事が分かった。これより，音源同定のための音圧測定範囲を正方形及び円形として 両者を比較した場合，本研究で示した例では円形の方が逆行列を安定化できる事が分かった.

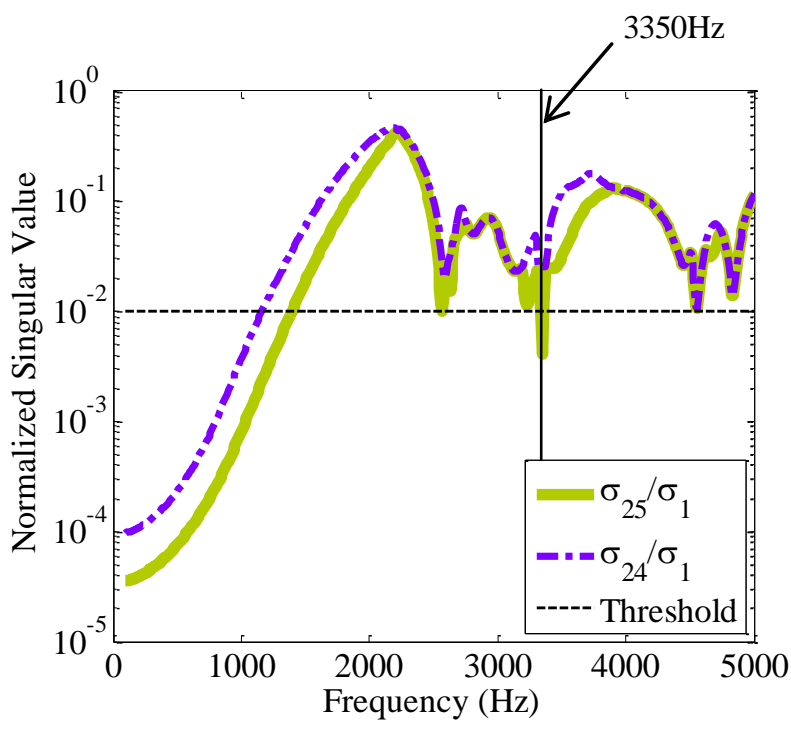

(a) Measurement area : square

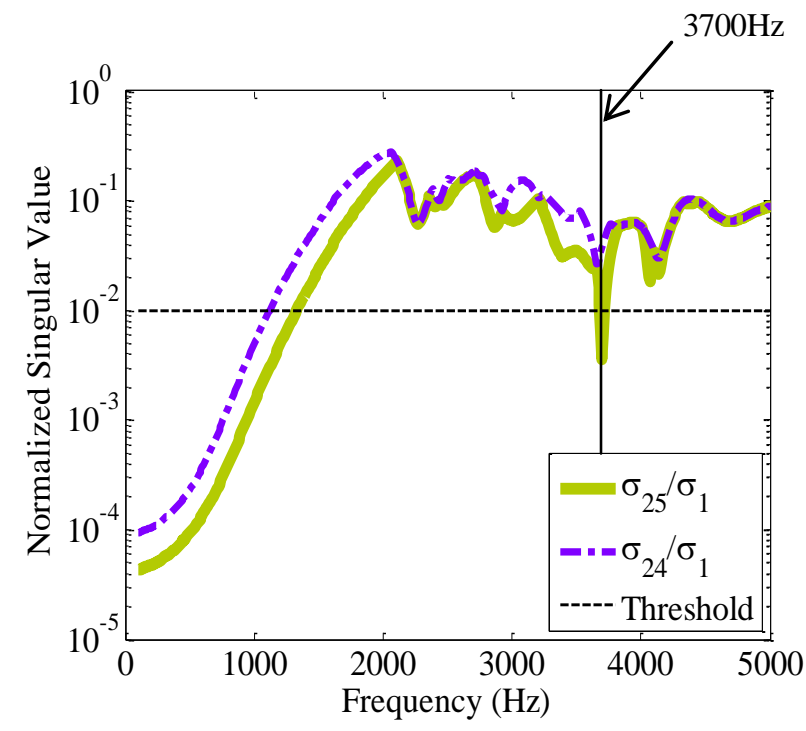

(b) Measurement area : circle

Fig. 2 Singular value plot of acoustic transfer function $\left(\sigma_{24} / \sigma_{1}\right.$ and $\left.\sigma_{25} / \sigma_{1}\right)$

\section{$3 \cdot 3$ 測定点数の増加}

最大特異值で正規化された最小特異值 $\sigma_{25} / \sigma_{1}$ を閾値よりも大きくして逆行列の不安定性を低減させるために, 測定点数を追加して改善させる事を試みた．音圧測定範囲が正方形の場合，測定点に新たに 4 点を加えて再計算 を行った．図1(a)で示すように，追加した測定点は $x, y$ 軸上に等間隔に並んだ点であり，座標は $(x, y)=(360$, $0),(0,360),(-360 ， 0) ，(0,-360)$ である. 再計算した結果を図3(a)に示す. 図3(a)の S-Initial は測定点 25 点を正 方形に配置した際の $\sigma_{25} / \sigma_{1}$ であり, S-Increased は測定点数を 4 点加えて測定点数を 29 点として再計算した結果を 表している. S-Increased は $2570 \mathrm{~Hz}$ 付近において閯值に近い值を取るが， $3350 \mathrm{~Hz}$ での值は閾值を大きく上回る. また, S-Initial と S-Increased の両者を比較すると， $4500 \mathrm{~Hz}$ 以上の高周波数域において特異值が改善されている事 が分かる．従って，全体として S-Increased は S-Initialよりも改善されている. 
音圧測定範囲が円形の場合にも同様に，測定点を新たに 4 点加えて再計算を行った．図 1(b)で示すように，追 加した測定点座標は $(x, y)=(285,285) ，(-285,285) ，(-285 ，-285) ，(285 ，-285)$ である．再計算した結果を図 3(b) に示す. 図 3(b)のC-Initial は測定点 25 点を円形に配置した際の $\sigma_{25} / \sigma_{1}$ であり, C-Increased は測定点数を 4 点加え て測定点数を 29 点として再計算した結果を表している. これらは測定間隔が $100 \mathrm{~mm}$ 以上となるように設定して いる(3). C-Increased は閾值を下回る值は見られず，C-Initial において逆行列が不安定となる周波数 $3700 \mathrm{~Hz}$ を含む 騒音解析領域内の周波数において, 闇值を上回っている事が分かる. これより, C-Increased は C-Initial に対して 改善されている.

次に，図 3(a)の S-Increased と図 3(b)の C-Increased を比較する. S-Increased は 2570Hz 付近において閯值に近い 值が含まれるのに対し，C-Increased は全般的に闇值を上回っている.これらは図 2 で示した最小特異值よりも一 つ大きい特異值である $\sigma_{24}$ が影響している事も考えられる. 図 $2(a)$ では $2570 \mathrm{~Hz}$ 付近の周波数において， $\sigma_{24}$ は最小 特異值である $\sigma_{25}$ に近い值となり，測定点を追加しても最小特異值に与える影響が小さい事が考えられる.

以上のように，測定点を適切な場所に追加する事で，逆行列の不安定性を低減する事ができ，音源同定の精度 が向上する事が分かる.

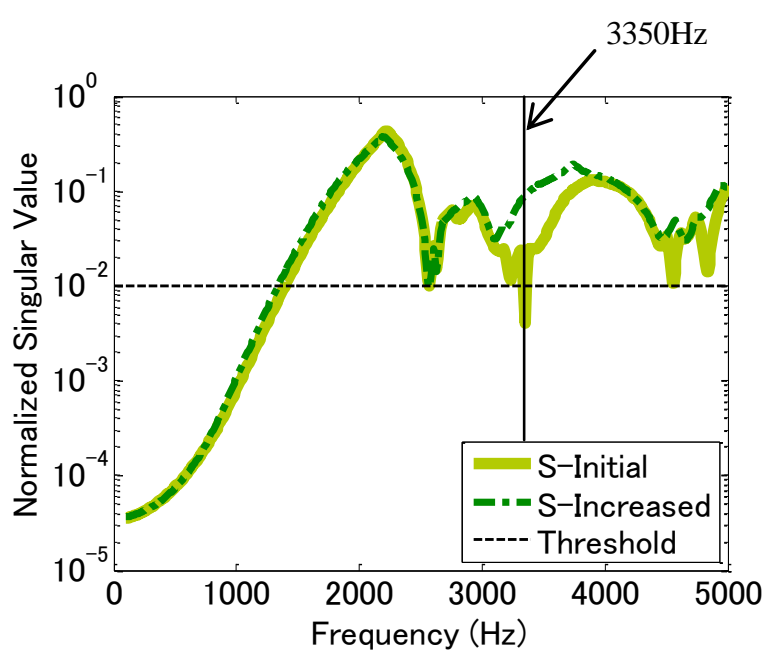

(a) Measurement area : square

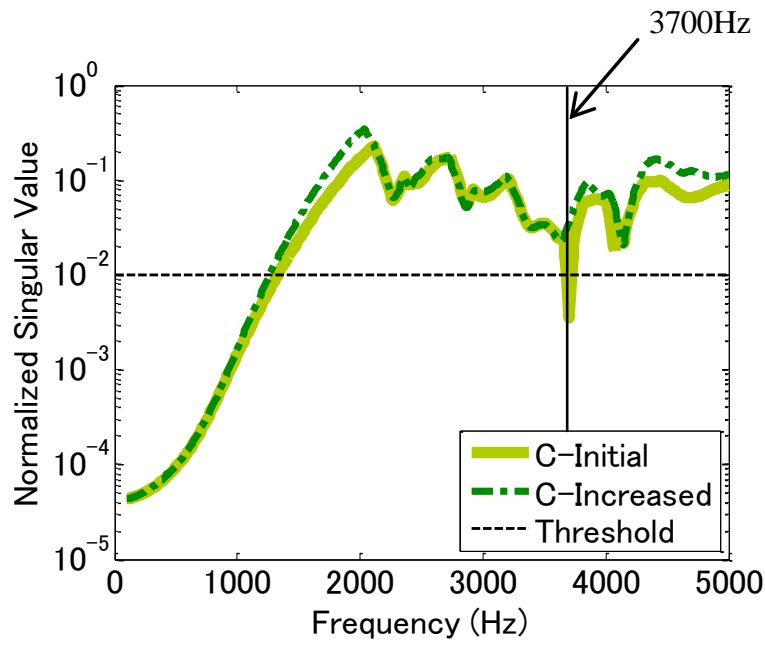

(b) Measurement area : circle

Fig. 3 Singular value plot of acoustic transfer function (Initial and Increased)

\section{4. 数值シミュレーションの検討}

測定点数を増加させたときと同様の効果，つまり音響伝達関数行列の逆行列の不安定性を低減させるように， 測定点を移動させる事で音源同定の精度向上を考える.

\section{$4 \cdot 1$ 特異值座標感度}

\section{$4 \cdot 1 \cdot 1$ 特異值座標感度の理論}

特異值座標感度とは，特定の周波数において，座標値をわずかに変更した際の特異值の変化を微分係数として 表したものである. $i$ 番目の測定点の座標 $\mathbf{p}_{i}=\left(x_{i}, y_{i}, z_{i}\right)$ 及び $j$ 番目の音源の座標 $\boldsymbol{q}_{j}=\left(X_{j}, Y_{j}, Z_{j}\right)$ とし，これら測 定点と音源の距離を $r_{i j}$ とすると，音響伝達関数は次のようになる.

$$
H_{i, j}=\frac{j S \omega \rho}{2 \pi r_{i j}} \exp \left(-\frac{j \omega r_{i j}}{c}\right)
$$

ここで，音源は固定されているとし， $\boldsymbol{q}_{j}$ は固定させて $\mathbf{p}_{i}$ を変化させるとする.$z$ 方向の変化を考えると, 


$$
\frac{\partial H_{i, j}}{\partial z_{i}}=\frac{\partial H_{i, j}}{\partial r_{i j}} \times \frac{\partial r_{i j}}{\partial z_{i}}=\frac{H_{i, j}}{r_{i j}}\left(z_{i}-Z_{j}\right)\left(-\frac{1}{r_{i j}}-\frac{j \omega}{c}\right)
$$

また, 測定点数 $i=1, \cdots, m$, 音源点数 $j=1, \cdots, n$ として音響伝達関数行列を表す.

$$
[H]=\left[\begin{array}{ccc}
H_{1,1} & \cdots & H_{1, n} \\
\vdots & \ddots & \vdots \\
H_{m, 1} & \cdots & H_{m, n}
\end{array}\right]=\sigma_{1} \mathbf{u}_{1} \mathbf{v}_{1}{ }^{H}+\cdots+\sigma_{n} \mathbf{u}_{n} \mathbf{v}_{n}{ }^{H}
$$

ただし， $\sigma_{1} \geqq \cdots \geqq \sigma_{n}$ である.

$\mathbf{u}, \mathbf{v}$ は $n$ 行の特異べクトルである. よって, $n$ 番目の特異值は次のようになる.

$$
\sigma_{n}=\mathbf{u}_{n}{ }^{H}[H] \mathbf{v}_{n}
$$

ここで，座標変化に対して $\mathbf{u}_{n}, \mathbf{v}_{n}$ の変化が微小であるとすれば，座標感度は次のように得られる.

$$
\frac{\partial \sigma_{n}}{\partial z_{i}}=\bar{u}_{n}^{(i)}\left[\frac{\partial H_{i, 1}}{\partial z_{i}} \quad \cdots \quad \frac{\partial H_{i, n}}{\partial z_{i}}\right]\left\{\begin{array}{c}
v_{1} \\
\vdots \\
v_{n}
\end{array}\right\}
$$

ただし, $\bar{u}_{n}{ }^{(i)}$ はべクトル $\boldsymbol{u}_{n}$ の複素共役の $i$ 番目の成分である.

特異值は実数の範囲にあるが，特異值の勾配は複素数になるため, 座標感度を改めて次式で定義する.

$$
\frac{\partial \sigma_{n}}{\partial z_{i}}=\operatorname{Re}\left[\bar{u}_{n}^{(i)}\left[\begin{array}{lll}
\frac{\partial H_{i, 1}}{\partial z_{i}} & \cdots & \frac{\partial H_{i, n}}{\partial z_{i}}
\end{array}\right]\left[\begin{array}{c}
v_{1} \\
\vdots \\
v_{n}
\end{array}\right]\right]
$$

式(16)をすべての測定点に応用する事で，全測定点の $z$ 方向の座標感度が得られる.

$$
\frac{\partial \sigma_{n}}{\partial \mathbf{z}}=\left\{\begin{array}{c}
\frac{\partial \sigma_{n}}{\partial z_{1}} \\
\vdots \\
\frac{\partial \sigma_{n}}{\partial z_{n}}
\end{array}\right\}=\operatorname{Re}\left[\mathbf{u}_{n}{ }^{H}\left[\begin{array}{ccc}
\frac{\partial H_{1,1}}{\partial z_{1}} & \cdots & \frac{\partial H_{1, n}}{\partial z_{1}} \\
\vdots & \ddots & \vdots \\
\frac{\partial H_{m, 1}}{\partial z_{m}} & \cdots & \frac{\partial H_{m, n}}{\partial z_{m}}
\end{array}\right]\left\{\begin{array}{c}
v_{1} \\
\vdots \\
v_{n}
\end{array}\right\}\right]
$$

$x$ 方向, $y$ 方向にも同様にする.

$$
\left.\frac{\partial \sigma_{n}}{\partial \mathbf{x}}=\operatorname{Re}\left[\mathbf{u}_{n}{ }^{H}\left[\begin{array}{ccc}
\frac{\partial H_{1,1}}{\partial x_{1}} & \cdots & \frac{\partial H_{1, n}}{\partial x_{1}} \\
\vdots & \ddots & \vdots \\
\frac{\partial H_{m, 1}}{\partial x_{m}} & \cdots & \frac{\partial H_{m, n}}{\partial x_{m}}
\end{array}\right]\right\} \begin{array}{c}
v_{1} \\
\vdots \\
v_{n}
\end{array}\right], \frac{\partial \sigma_{n}}{\partial \mathbf{y}}=\operatorname{Re}\left[\mathbf{u}_{n}{ }^{H}\left[\begin{array}{ccc}
\frac{\partial H_{1,1}}{\partial y_{1}} & \cdots & \frac{\partial H_{1, n}}{\partial y_{1}} \\
\vdots & \ddots & \vdots \\
\frac{\partial H_{m, 1}}{\partial y_{m}} & \cdots & \frac{\partial H_{m, n}}{\partial y_{m}}
\end{array}\right]\left\{\begin{array}{c}
v_{1} \\
\vdots \\
v_{n}
\end{array}\right]\right]
$$

式(17)及び(18)を 3 次元座標に対する座標感度の式として定義する.

\section{$4 \cdot 1 \cdot 2$ 特異值座標感度の適用}

座標感度により測定点数を移動させる事で改善を試みた. 本研究では, $x$ 軸, $y$ 軸方向に限定して座標感度を適 用している. 音圧測定範囲が正方形の場合, ランク落ちする周波数である $3350 \mathrm{~Hz}$ に感度を適用して再計算した. ここで，測定点同士の干渉を考慮し，感度べクトルに一定量の係数を乗じる事で測定点を移動させた，一定量の 係数とは, 座標感度の中で最大值を用いて全測定点の座標感度を正規化し, 得られた座標感度に許容できる移動 量を乗じた值である．座標感度により測定点を移動させた結果を図 4(a)の Modified に示し，正規化した最小特異 值を図 5(a)の S-Sensitivity に示す．図4(a)より，座標感度により $x y$ 座標の原点に向かい測定点を再配置している 事が分かる. また, 直線の式 $y=x$ 及び $y=-x$ 上にある 9 点の測定点の座標感度はほぼ 0 であり, 再計算しても移 
動していない事が分かる.これら 9 点は対象周波数の特異值に与える影響が少なく, 移動する必要がないと考え られる。

S-Sensitivity より，対象周波数 $3350 \mathrm{~Hz}$ における特異值が闇值を大きく上回る事がわかるため，逆行列の不安定 性が低減されている。一方で, $2580 \mathrm{~Hz}$ 及び $4720 \mathrm{~Hz}$ 付近では特異值が閾值を下回り, 逆行列は不安定となる。 こ れは S-Initialにおいて閯值に近い值を持っていた周波数であり, 対象周波数に対して座標感度を適用し, その周 波数において逆行列の不安定性は低減されたが，他の周波数では悪化したと考えられる.

音圧測定範囲が円形の場合も同様にして, $3700 \mathrm{~Hz}$ における感度を用いて再計算した. 座標感度により測定点を 移動させた結果を図 4(b)の Modified に示し, 再計算して得られた正規化された最小特異值を図 5(b)の C-Sensitivity に示寸．図4(b)は図4(a) とは異なり，座標感度により $x y$ 座標の原点から遠ざかるように測定点を再配置している 事が分かる. また, 直線の式 $x=0$ 及び $y=0$ 上にある 9 点の測定点の座標感度はほぼ 0 であり, 再計算しても移 動しない点である.これら 9 点は対象周波数の特異值に与える影響が少なく, 移動する必要がないと考えられる.

C-Sensitivity より，対象周波数 $3700 \mathrm{~Hz}$ における特異值が閾值を大きく上回る事が分かるため，対象周波数にお いて逆行列の不安定性は低減される一方，対象周波数付近である $3610 \mathrm{~Hz}$ では特異值が閾值を下回り，逆行列は 不安定となる。これは C-Initial において特異值が閾值に近い值を持っていた周波数である事が原因として考えら れる.

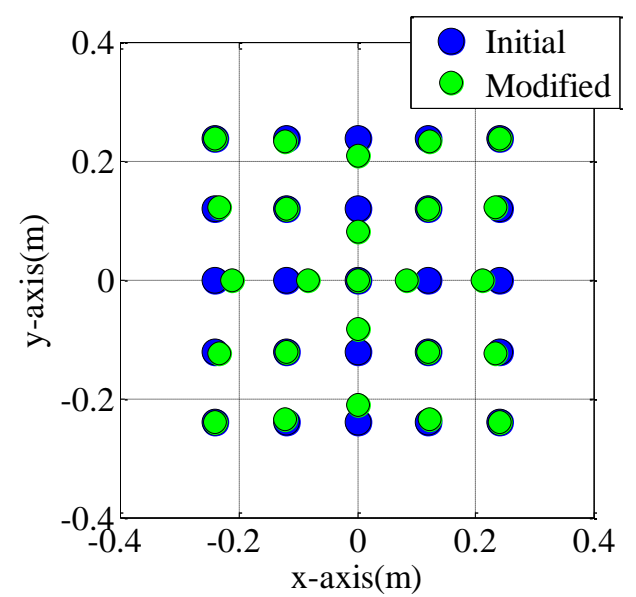

(a) Measurement area : square

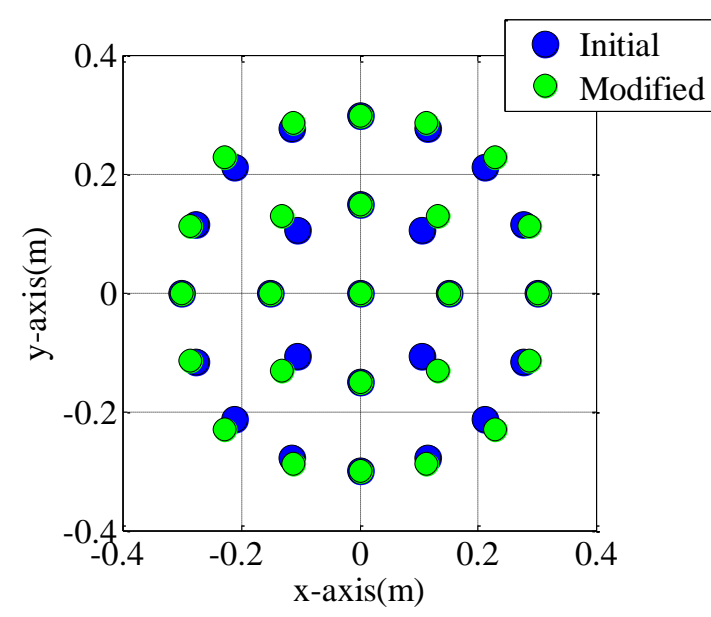

(b) Measurement area : circle

Fig. 4 Coordinates of measurement points (Sensitivity Analysis)

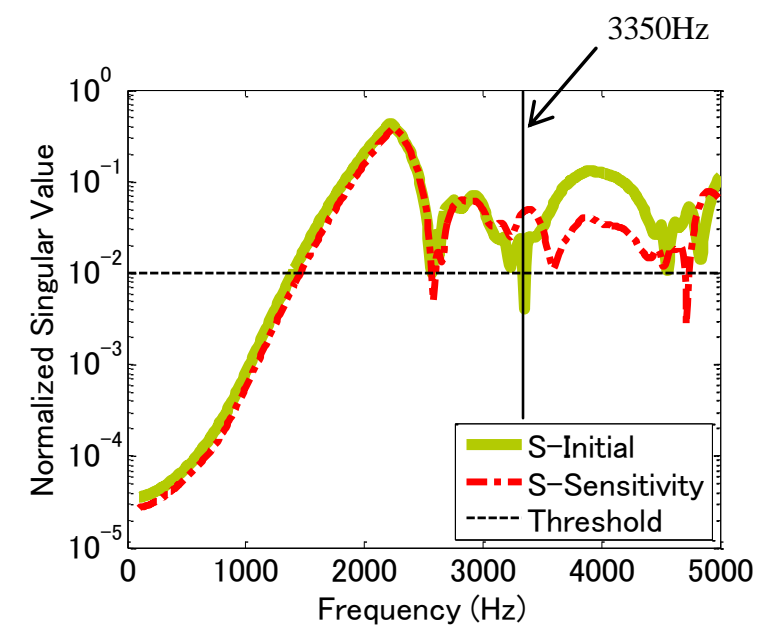

(a) Measurement area : square

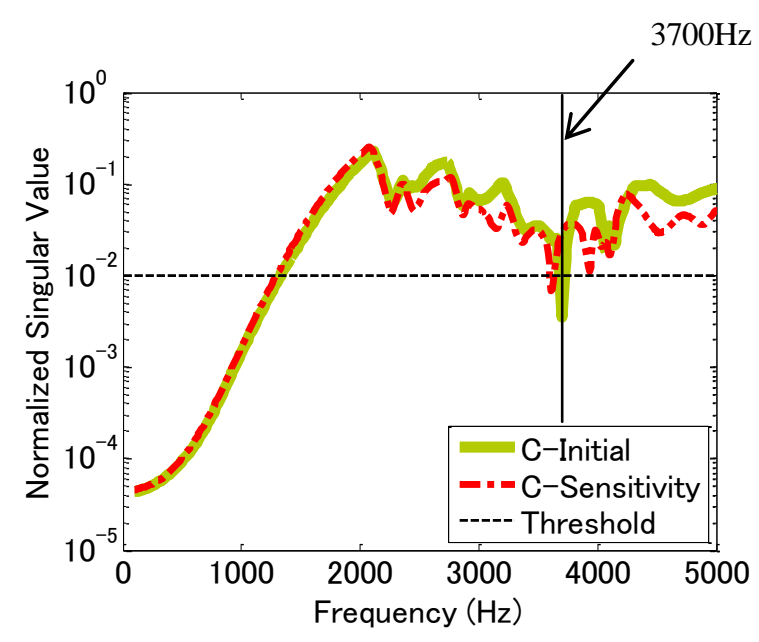

(b) Measurement area : circle

Fig. 5 Singular value plot of acoustic transfer function (Initial and Sensitivity) 


\section{$4 \cdot 1 \cdot 3$ 特異値座標感度の繰り返し計算}

座標感度を適用して再計算した結果から, S-Sensitivity では $2580 \mathrm{~Hz}$ 及び $4720 \mathrm{~Hz}$ 付近の周波数において正規化 した特異值が閾值を下回る事が分かった．また，C-Sensitivity では $3610 \mathrm{~Hz}$ 付近の周波数において，特異値が閾値 を下回る事が分かった，そこで，それぞれ閾值を下回った周波数を新たに対象周波数とし，引き続き座標感度を 用いて再計算した。再計算して測定点を移動させた結果を図 6 に示し，正規化した最小特異值を図 7 に示す.

音圧測定範囲が正方形の場合，座標感度により測定点を移動させた結果を図 6(a)の Modified2 に示し，図 7(a) の S-Sensitivity2 はS-Sensitivity を用いて再度計算した結果である. 図4(a)と比較すると, 座標感度を繰り返し適 用する事により， $x y$ 座標の原点へより大きく測定点を移動させている事が分かる. 2 つの対象周波数において逆 行列の不安定性は低減されているが，新たに $4250 \mathrm{~Hz}$ 付近の周波数で特異值が闇值を下回る. 繰り返し計算を続 行するため, 対象周波数を $4250 \mathrm{~Hz}$ として再計算しても, 閾值を下回る特異值が現れる事が分かった.

また，音圧測定範囲が円形の場合では，座標感度を繰り返し計算しても，対象周波数付近の特異值は閾值を下 回る事が分かった.

以上から, 対象周波数に対する座標感度を求めて測定点を移動させると，その周波数において逆行列の不安定 性が低減する測定点の配置が得られる事が分かった。しかし, 繰り返し座標感度を用いて計算しても騒音解析領 域内の周波数全体を改善させる事は出来ない事が分かった.

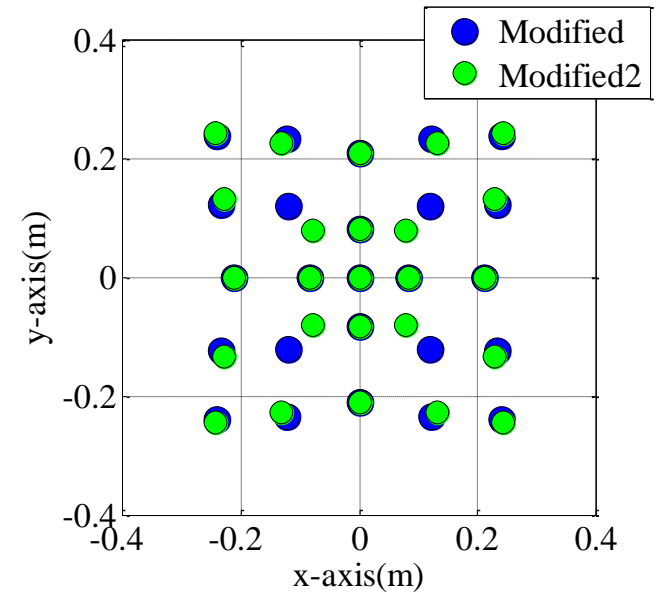

(a) Measurement area : square

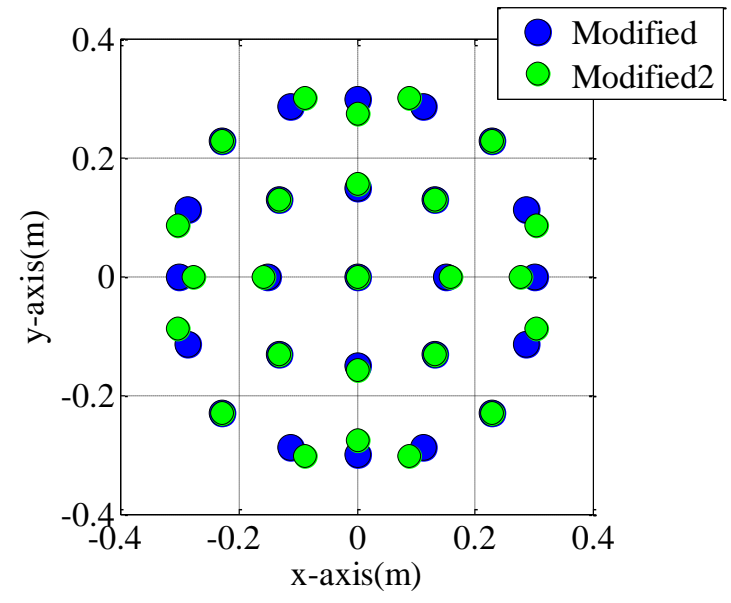

(b) Measurement area : circle

Fig. 6 Coordinates of measurement points (Sensitivity analysis)

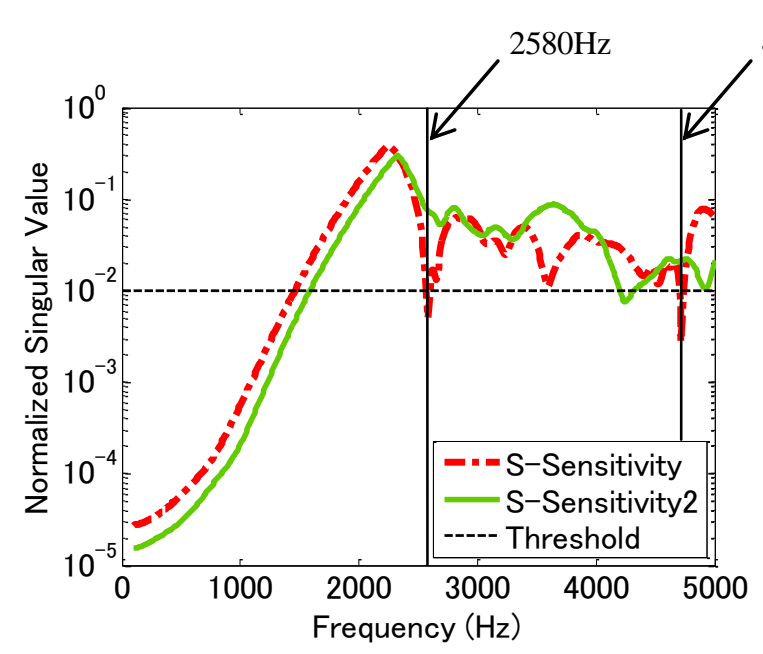

(a) Measurement area : square

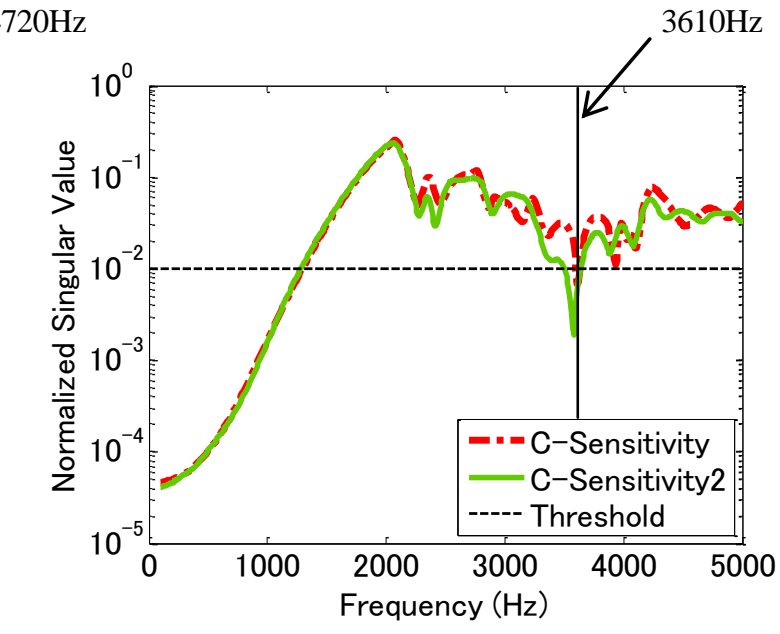

(b) Measurement area : circle

Fig. 7 Singular value plot of acoustic transfer function (Repeated sensitivity) 


\section{$4 \cdot 2$ 正規乱数}

座標感度を適用して計算を行った結果，対象周波数の特異值の夕改善され，その他の周波数において特異值が 閾值を下回る事が分かった．この原因の一つとして，測定点を規則的に配置させた事が考えられる．そこであえ て測定点に不規則性を持たせる事で，精度が改善される可能性もあると考えた.

測定点をランダムにばらつかせるために, $x$ 座標, $y$ 座標に対して, 平均 0 , 標準偏差 $10 \mathrm{~mm} の 2$ 次元正規分布 に従い測定点を移動させる事を試みた。試行を何回か繰り返し， $1400 \mathrm{~Hz}$ 以上の騒音解析領域において，すべての 特異值が閾值を超える準最適な測定点配置となる結果が得られた時点で終了寸る計算を行った．音圧測定範囲が 正方形の場合における測定点の配置を図 8(a)の Modified に示し，再計算して得られた正規化した最小特異値が図 9(a)で示す S-Distribution である.

準最適な測定点配置となる S-Distribution の結果が得られるまでに繰り返し行った試行回数は 4963 回である. S-Distribution は騒音解析領域における值が閾値を超え, 全体として S-Distribution は S-Initial よりも改善された事 が分かる.

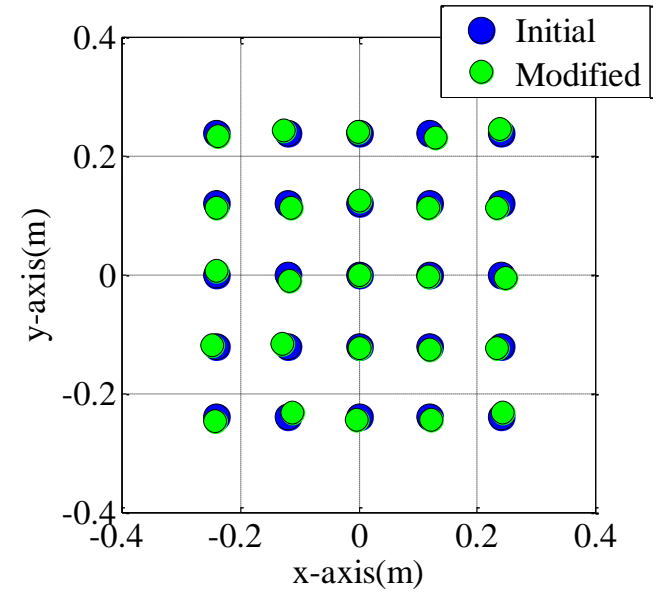

(a) Measurement area : square

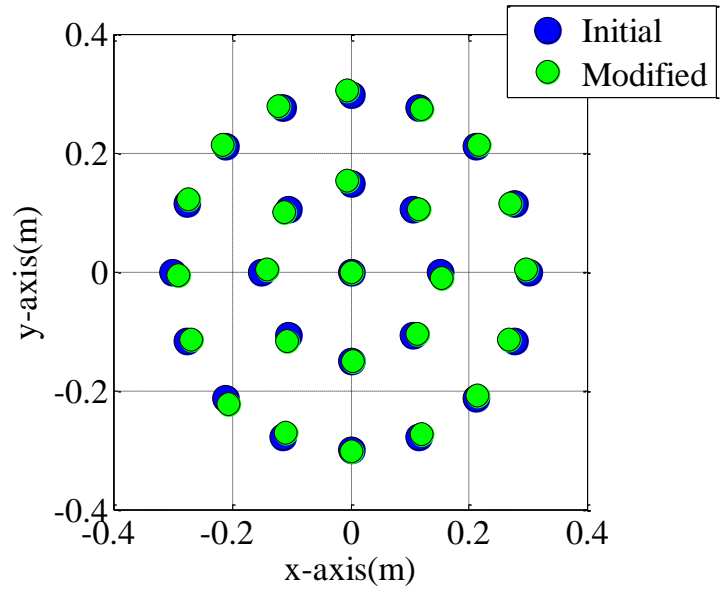

(b) Measurement area : circle

Fig. 8 The coordinates of measurement points (Normal Distribution)

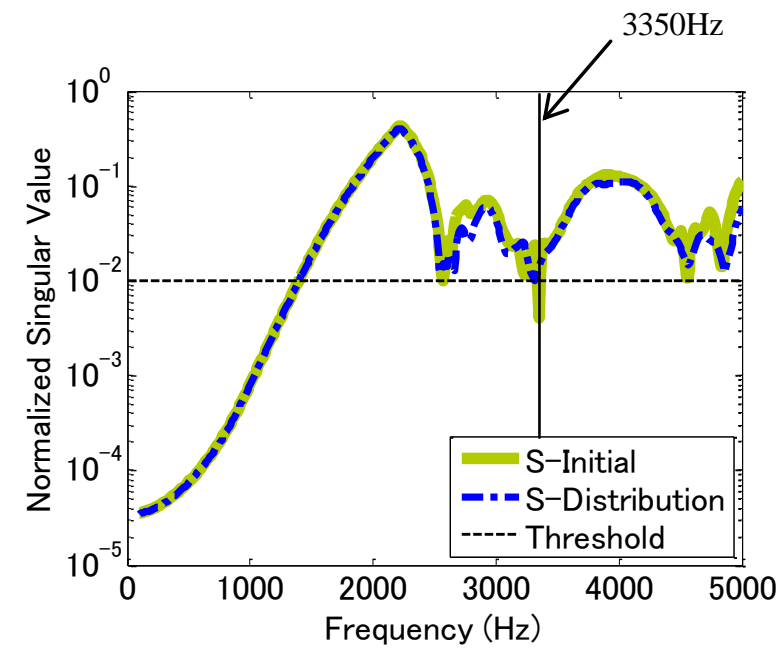

(a) Measurement area : square

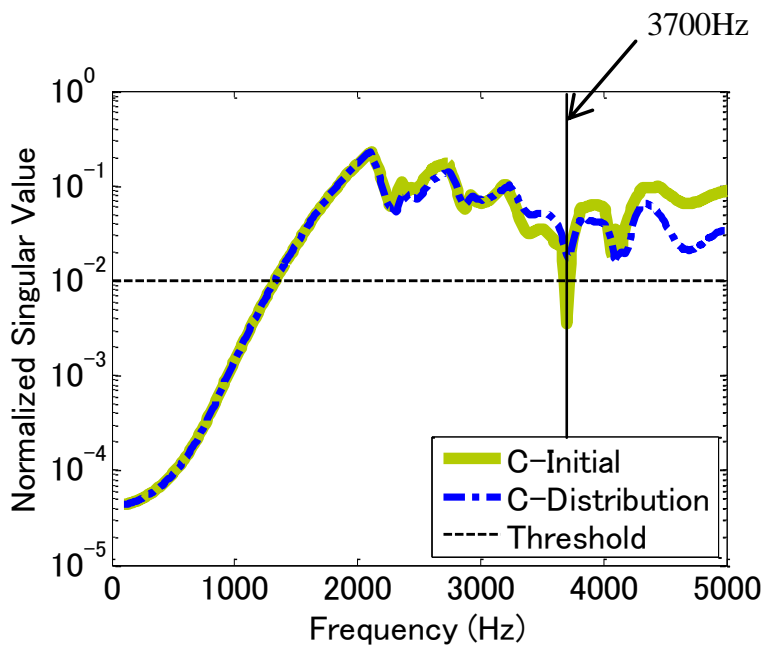

(b) Measurement area : circle

Fig. 9 Singular Value Plot of Acoustic Transfer Function (Initial and Distribution) 
ここで，標準偏差を小さくして計算を行った場合について述べる．標準偏差を $8 \mathrm{~mm}$ として計算すると，試行 回数が 7490 回を超えたあたりで準最適な測定点配置を取る. 標準偏差を $7 \mathrm{~mm}, 6 \mathrm{~mm}$ のように徐々に小さくして 計算すると, それに伴い試行回数は増加して計算が終了した. さらに標準偏差を小さくして $5 \mathrm{~mm}$ で計算すると, 準最適な測定点配置を取る事なく，十分に大きく設定した回数で試行は終わらなかった．標準偏差を小さくする と，測定点が移動できる量は小さくなるため，全体的に閾值を上回る事が難しく，標準偏差を大きくすると，そ れに比例して測定点の移動可能な量が大きくなる．このため，全体的に閾值を上回る測定点の配置が存在する確 率は高くなり, 比較的短時間で試行が終わる事が分かる.ここでは, 測定点同士の干渉を考慮し, 標準偏差を $10 \mathrm{~mm}$ として計算を行った.

音圧測定範囲が円形の場合にも，同様にして正規乱数を用いて測定点を移動させた．測定点の配置を図 8(b)の Modified に示し，再計算して得られた正規化した最小特異值が図 9(b)に示す C-Distribution である. C-Distribution は騒音解析領域における值が全体的に閾值を上回り，C-Initial に対して改善された事が確認できる.

音圧測定範囲が正方形及び円形の両者を試行時間から比較すると, 円形の方が正方形に配置したものよりも試 行回数が少なく, 比較的短時間で試行が終わった。これより試行時間の観点からみても, 円形の方が逆行列の不 安定性を低減できる事が分かった。

\section{5. 結言}

本研究では, 平板を対象構造物として音響伝達関数による音源同定の精度向上を検討した.

・音源同定のための音圧測定範囲を正方形及び円形として両者を比較し，本研究で示した例では円形の方が逆行 列を安定化できる事が分かった.

・音響伝達関数の逆行列が不安定となる場合，座標感度により測定点を移動させ，特定の周波数に対する不安定 性を低減できる事が分かったが，その他の周波数に対して逆行列が不安定となる場合がある事も分かった。

・音響伝達関数の逆行列が不安定となる場合，正規乱数を用いて座標を移動させる事で，その不安定性を低減で きる事が分かった．しかし繰り返し計算を行い良好な結果を選ぶ際に，限られた試行回数では結果が得られな い場合もある事が分かった.

以上をまとめると，特定の周波数に対して逆行列の不安定性を大きく低減させるには，座標感度により測定点 を移動させる方法が有効であり, 周波数全体で測定精度を向上させるには, 正規乱数が有効である事が分かった.

本研究では, 2 次元平板モデルを対象構造物として, その平面上の各点から放射される音圧を, 音圧測定範囲

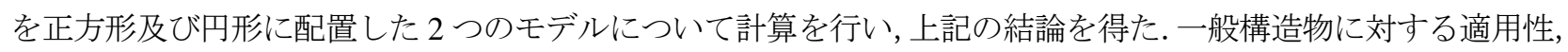
測定条件が異なる場合の同定可能性等，本研究で得られた結論の一般性についてはさらに検討をする必要がある と考えるが, 音響伝達関数の特異值を基に, 音源の計測精度を評価し改善するという方法が有効であると考える.

\section{文献}

（1） 河村庄造，雲丹亀正記，岩营卓三，“音圧測定による機械の振動状態の推定（音響・振動系逆問題解析における不 適切性低減手法の提案)”，日本機械学会論文集 C 編，Vol. 66, No. 652 (2000), pp. 99-106.

(2) H. Defosse, F. Damagnez, M.A. Hamdi, S. Frikha, F. Ollivier, P. Varet, T. Beauvilain, "Engine noise characterization using an inverse boundary element method", Proceedings of ISMA25, Vol.3 (2000), pp.1253-1260.

(3) J. Liu, J. Han, D.W. Herrin, "Sound Field Reconstruction using Inverse Boundary Element Method", Proceedings of the IMAC-XXVII, Vol.1 (2009), pp. 317-324.

(4) Fredy Martinus, David W.Herrin, Andrew F.Seyberth, "Selecting Measurement Locations to Minimize Reconstruction Error using the Boundary Element Method", Journal of Computational Acoustics, Vol.15, No.4 (2006), pp531-555.

(5) T. Koizumi, N. Tsujiuchi, Y. Isome and H. Uehara, "Optimizing the Number of Measurement Points for Noise Source Identification by Inverse Boundary Element Method", Proceedings of the ASME (2008), pp.3127-3138.

（6）鈴木浩平，西田公至，丸山晃市，渡辺武，“機械工学のための振動・音響学”，初版 (1996), pp. 153-178, サイエン 又社. 